\title{
Kan elektromagnetiske felter gi astma?
}

\section{Eksponering for elektromagnetiske felter i svangerskapet er assosiert med astma hos barna.}

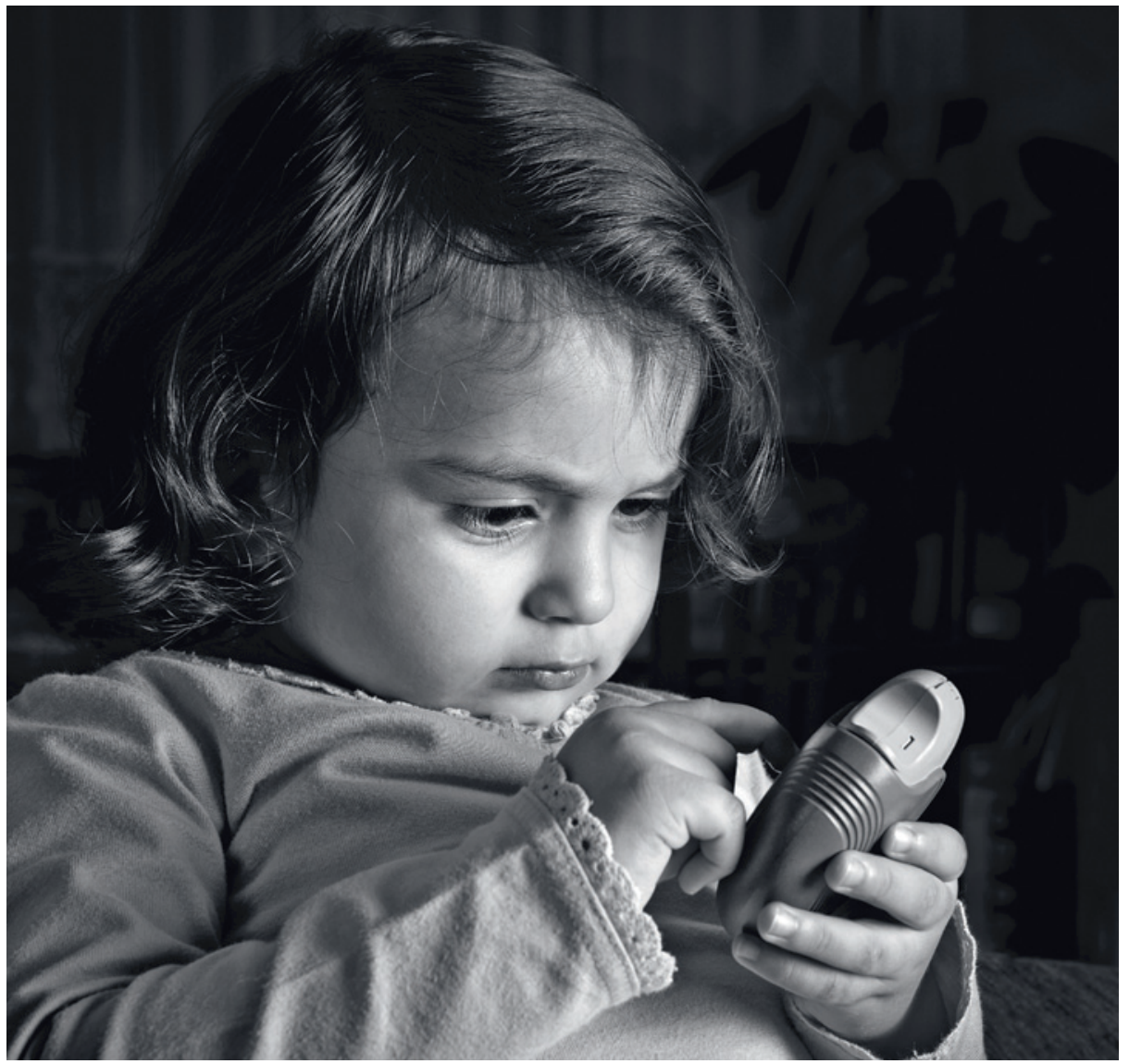

Illustrasjonsfoto Istockphoto
I en studie i California fra 1996-98 ble gravide utstyrt med et måleapparat som registrerte elektromagnetisk stråling (1). I de neste 13 årene utviklet 130 av de 626 barna disse kvinnene fødte astma.

Det var et lineært dose-respons-forhold mellom økende median daglig eksponering for elektromagnetisk stråling under svangerskapet og astma hos barna - justert for potensielle konfunderende faktorer. For hver øning på $1 \mathrm{mG}$ av maternell eksponering var det en $15 \%$ økning av astma (justert hasardratio 1,15; $95 \%$ KI 1,04-1,27). Barn av mødre med høyere eksponeringsnivåer hadde 3,5 ganger økt hyppighet av astma enn barn av mødre med lavere nivåer (justert hasardratio 3,52; 1,68-7,35).

- Et hovedproblem med studien er at de elektromagnetiske feltene er så lave at det ikke er funnet noen virkningsmekanisme på molekylært nivå som tilsier at vi skal kunne forvente noen effekt, sier førsteamanuensis Arnt Inge Vistnes ved Fysisk institutt, Universitetet i Oslo. Han har forsket på slike effekter i mange år. - Jeg sluttet fordi jeg mistet troen på at det kunne være noen nevneverdig biologisk effekt av så svake felter som det her er snakk om, sier han.

\section{Erlend Hem}

erlend.hem@medisin.uio.no

Tidsskriftet

\section{Litteratur}

1. Li DK, Chen H, Odouli R. Maternal exposure to magnetic fields during pregnancy in relation to the risk of asthma in offspring. Arch Pediatr Adolesc Med 2011; 165: 945-50.

\section{Yoga kan hjelpe mot ryggsmerter}

\section{Et 12 ukers treningsprogram med yoga ved kroniske korsryggssmer- ter ga bedre resultater enn vanlig behandling.}

Yoga er en kombinasjon av mentale og kroppslige teknikker, bl.a. fysisk trening og avslapning. Mindre studier tyder på at yoga kan ha effekt ved kroniske korsryggssmerter.

I en britisk studie ble 313 voksne med kroniske eller residiverende korsryggssmerter rekruttert fra allmennpraksis og randomisert til et 12 ukers yogaprogram eller til vanlig behandling (1). Begge gruppene fikk utdelt råd for vond rygg skriftlig. Alle deltakerne fikk tilsendt validerte spørreskjemaer for ryggfunksjon (Roland-Morris
Disability Questionnaire; RMDQ), ryggsmerter og generell helse.

Nesten to tredeler av dem som ble tilbudt yoga, gjennomførte minst seks av 12 yogatimer. Etter tre, seks og 12 måneder hadde disse pasientene bedre ryggfunksjon enn dem som fikk vanlig behandling. Forskjellen i gjennomsnittlig justert RMDQ-skår var henholdsvis 2,17 (95\% KI 1,03-2,71), 1,48 $(0,33-2,62)$ og $1,57(0,42-2,91)$ til fordel for yoga. Resultatet når det gjaldt ryggsmerter og generelle helsemål var imidlertid likt i begge grupper. Åtte pasienter i yogagruppen rapporterte om mer smerter.

- Denne studien er større enn tidligere studier og underbygger mange ryggpasienters gode erfaringer med yoga, sier professor John-Anker Zwart ved Oslo universitetssykehus. Han leder Formidlingsenheten for muskel- og skjelettlidelser. - Yoga så ikke ut til å bedre selve ryggsmertene mer enn vanlig behandling, men bedret funksjonen.

Pasienter med kroniske ryggsmerter kan trygt prøve yoga, selv om noen kan oppleve forverring. Studien gir ikke grunnlag for å endre gjeldende norske retningslinjer for behandling av kroniske korsryggssmerter, som anbefaler ulike former for trening og øvelser og det å være fysisk aktiv, sier Zwart.

\section{Petter Gjersvik \\ petjense@online.no \\ Tidsskriftet}

\section{Litteratur}

1. Tilbrook HE, Cox H, Hewitt CE et al. Yoga for chronic low back pain. A randomized trial. Ann Intern Med 2011: 155: 569-78. 